Reprod. Nutr. Dévelop., 1983, 23 (5), 817-828.

\title{
Effect of lasalocid sodium on rumen fermentation and digestion in sheep
}

\author{
P. THIVEND, J.-P. JOUANY
}

Laboratoire de la Digestion des Ruminants, I.N.R.A., Theix, 63122 Ceyrat, France.

Summary. Four adult sheep were fed 4 diets successively according to a Latin-square design. They were fitted with a rumen cannula and with simple cannulae at the duodenum and ileum. The basal diet $\left(L_{0}\right)$ was composed of highly-pressed ensiled sugar beet pulp $(56.2 \%)$, cereal (barley and corn : $27.6 \%)$, urea $(1.5 \%)$ and wheat straw $(14.1 \%)$. Lasalocid sodium was added to obtain the following respective amounts : $21 \mathrm{ppm}$ for diet $L_{1}, 43 \mathrm{ppm}$ for diet $L_{2}$ and $64 \mathrm{ppm}$ for diet $L_{3}$ (table 1).

In the rumen, lasalocid significantly increased the molar proportion of propionic acid in the volatile fatty acids (VFA) mixture at the expense of the acetic and butyric acid proportions. The total VFA concentration decreased, especially with 43 and $64 \mathrm{ppm}$ (table 2). Accordingly, the proportion of methane in rumen gases decreased. The ciliate population was always lower in animals fed experimental diets $L_{1}, L_{2}$, and particularly $L_{3}$. The non-food-particle-associated bacterial population also decreased ; the differences were significant only with the highest doses of lasalocid $\left(L_{3}\right)$. At the same time, bacterial cellulolytic activity increased $10 \%$, indicating that qualitative modifications had taken place in the rumen bacterial population (table 3 ).

Overall digestive utilization of organic matter (OM) decreased when lasalocid was added to the diets. This was due to a considerable reduction in forestomach digestion (12\% decrease) (table 4). A greater supply of OM rich in cell-wall carbohydrates in the duodenum would explain the lower digestibility in the small intestine of animals given diet $L_{1}$ and especially the $L_{2}$ and $L_{3}$ diets. No significant shift in digestion was noted in the large intestine.

The composition of the non-ammonia nitrogen that entered the duodenum of sheep given lasalocid differed from that noted with the control diet $\left(L_{0}\right)$ (table 5 ). The amount of microbial proteins was significantly lower, whilst the proportion of non-degraded feed proteins was higher. The efficiency of microbial synthesis (bacterial proteins/ $\mathrm{kg}$ OM truly digested in the rumen) was not significantly modified by lasalocid.

All these modifications in digestion observed with these diets, and resulting from changes in the qualitative and quantitative composition of flora and fauna in the rumen, have an effect on nitrogen and energy utilization in the ruminant.

\section{Introduction.}

Lasalocid is an ionophore that is widely used in avian husbandry because of its anticoccidian properties. Owing to the fact that it renders membranes permeable to the passage of mono- and divalent cations, its antimicrobial action 
favourably mudifies rumen bacterial and protozoal populations, thus making better use of feeds.

In fact, lasalocid, like other ionophores and antibiotics such as monensin and salinomycin, has been shown to increase propionic acid production and reduce methane formation in the ruman (Bartley et al., 1979 ; see review of Durand, 1982). These results could be due to the selection of bacteria producing succinate and fermenting lactate and the inhibition of those producing acetate, butyrate and lactate as end-products, and formiate and hydrogen as intermediary precursors to methane.

To our knowledge, these are the only facts available on the role of lasalocid in ruminant digestion. In particular, very little work has been done to quantify the modifications of microbial digestion induced by this product in the feed. This paper reports a study of the extent of digestion in different parts of the digestive tract and of the nature of the end-products of digestion in the rumen as a function of the amount of lasalocid given. We used sheep fed diets rich in highlypressed, ensiled sugar beet pulp. The use of these diets to fatten cattle in beetproducing areas of France is steadily increasing.

\section{Material and methods.}

Animal feed and experimental design. - Four adult Texel sheep fitted with a rumen cannula and with simple cannulae at the duodenum and ileum were given successively 4 different feeds (LO, L1, L2, L3) according to a Latin-square design. During the last period, the control animal had to be replaced by another identical animal because it refused to eat properly.

The 4 respective diets studied contained $0(L 0), 21(L 1), 43(L 2)$ and 64 (L3) ppm of lasalocid sodium. The feed was made up of highly-pressed, ensiled sugar beet pulp $(56.2 \%)$, cereal (barley and maize $27.6 \%$ ), urea $(1.5 \%$ ) and chopped wheat straw $(14.1 \%$ ) (table 1$)$. The feed rations were prepared daily and

TABLE 1

Diet composition.

\begin{tabular}{|c|c|c|}
\hline \multirow[t]{2}{*}{ Ingredients } & \multicolumn{2}{|c|}{ Intake (\%) } \\
\hline & Fresh matter & Dry matter \\
\hline Highly-pressed and ensiled sugar beet pulp . & 86.4 & 56.3 \\
\hline Ground and pelleted corn $\ldots . \ldots \ldots \ldots \ldots$ & 2.9 & 9.1 \\
\hline Ground and pelleted barley (i). & 5.8 & 18.5 \\
\hline Chopped wheat straw ........ & 4.3 & 14.1 \\
\hline Urea...$\ldots \ldots \ldots \ldots$ & 0.4 & 1.5 \\
\hline Minerals and vitamins & 0.2 & 0.5 \\
\hline Chemical analysis & & \\
\hline Organic matter .... & & 94.1 \\
\hline$\ldots \ldots \ldots \ldots \ldots$ & & 2.4 \\
\hline P.D.I.E. $(\mathrm{g} / \mathrm{kg}) \quad \ldots \ldots \ldots$. & & 100.0 \\
\hline P.D.I.N. $(\mathrm{g} / \mathrm{kg}) \ldots \ldots \ldots \ldots \ldots \ldots \ldots \ldots \ldots$ & & 100.2 \\
\hline
\end{tabular}

(1) Containing 115,232 or $348 \mathrm{ppm}$ of lasalocid sodium. 
given in two equal meals. The sheep had access to water and salt licks at all times.

The animals were fed ad libitum for the first 3 weeks; then they received an amount of feed corresponding to the intake of the animal that ate the least over that period. Food intake was controlled throughout the experiment. Water intake was controlled only during the last period.

Each experimental period lasted 6 weeks. It took the sheep 3 weeks to adapt to the diet. Digestibility measurements were taken during the 4th week. The digestive contents were sampled during the 5 th week, and gas composition as well as cellulolytic activity were determined during the 6th week of each period.

Ten days prior to sampling, cellulose powder impregnated with chromic oxide $\left(\mathrm{Cr}_{2} \mathrm{O}_{3}\right)$ (Tisserand et al., 1962) was introduced directly into the rumen through the cannula at each feeding at the rate of $2.2 \mathrm{~g}$ of $\mathrm{Cr}_{2} \mathrm{O}_{3}$ per day.

\section{Sampling.}

a) Diet digestibility was determined by total faeces collection over an 8-day period. Part $(50 \%)$ of the faeces excreted daily were dried for $48 \mathrm{~h}$ in a forced-air oven. A feed sample was taken daily and dried similarly.

b) Samples of the contents of the rumen (to determine bacterial $\alpha$ - $\epsilon$ diaminopimelic acid) and of the duodenum and ileum were taken every $6 \mathrm{~h}$ for 2 days, staggering the first sampling of the second day by $3 \mathrm{~h}$ (collection at 3, 9, 15, 21, $6,12,18 \mathrm{~h}$ and midnight). The digestive contents were collected in plastic containers and frozen immediately at $-20^{\circ} \mathrm{C}$. A representative sample from each of the eight samples was pooled for each animal.

c) When the duodenal and ileal contents were collected, rumen liquor samples were taken to measure $\mathrm{pH}$, VFA concentration and composition, ammonia nitrogen content, and to isolate representative bacterial samples. Samples were also taken at 1,2 and $4 \mathrm{~h}$ after the morning meal to study postprandial changes in the digestion end-products. Rumen liquor samples were taken from the bottom of the rumen ventral pouch and filtered through a $1-\mathrm{mm}^{2}$ mesh metal screen. Ten milliliters of filtered liquor were mixed with $1 \mathrm{ml}$ of additive $\left(\mathrm{H}_{3} \mathrm{PO}_{4} 5 \%+\mathrm{HgCl}_{2} 1 \%\right)$ to analyse VFA, and $5 \mathrm{ml}$ of iltered liquor were added to $20 \mathrm{ml}$ of a $12.5 \% \mathrm{NaCl}$ solution to determine ammonia nitrogen. Rumen gas samples were taken at 0, 1, 4 and $6 \mathrm{~h}$ (Jouany and Senaud, 1979) after food intake.

d) Samples to measure the protozoal population were taken $1 \mathrm{~h}$ after the morning meal for 5 consecutive days. The protozoa were counted according to Jouany and Senaud (1982). Using a particle counter (Coulter Counter), non-food particle-associated bacteria were counted in a representative rumen liquor sample every $3 \mathrm{~h}$ for $24 \mathrm{~h} ; 0.1 \mathrm{ml}$ of filtered rumen liquor, to which three drops of $30 \%$ formalin had been added, was brought to a final volume of $10 \mathrm{ml}$ with a $0.5-\mu$ filtered saline solution, then stored at $+4{ }^{\circ} \mathrm{C}$. Lastly, the cellulolytic activity of rumen bacteria, measured by the nylon bag method (Jouany and Senaud, 1982), was determined by the weight loss of the wheat straw enclosed in the nylon bag that had remained inside the rumen for $48 \mathrm{~h}$. Four bags were used per period per animal. 
Chemical analysis. - Dry matter and ash in feed, faeces and duodenal and ileal contents were analysed by classical methods. Total nitrogen was determined (Kjeldahl method) on the fresh samples. Ammonia nitrogen was measured by the method of Conway. Chromic oxide was determined by the procedure of Mathieson (1970), modified to obtain a linear relationship between optical density and $\mathrm{Cr}_{2} \mathrm{O}_{3}$ concentration. The concentration and composition of VFA mixtures in the rumen were determined by gas-chromatography (Jouany, 1982), and rumen liquor ammonia nitrogen by the procedure of Berthelot (see Michel, 1971). Rumen gas samples were analysed by gas-chromatography (McArthur and Miltimore, 1961).

Bacterial nitrogen content in the duodenum was estimated by determining $\alpha-\epsilon$ diaminopimelic acid in the duodenal contents and samples of rumen bacteria. The latter were obtained by centrifuging samples of the rumen content taken from the same animals simultaneously with the duodenal samples.

The amount of undegraded dietary nitrogen in the rumen, calculated as the difference between non-ammonia nitrogen and bacterial nitrogen content of the duodenal digesta, included protozoal and endogenous nitrogen. This is referred to as non-bacterial non-ammonia nitrogen (NBNAN). The truly digested organic matter in the rumen was estimated by adding the organic matter from the bacteria to the organic matter apparently digested in the rumen. The former was determined by the amount of bacterial nitrogen flowing at the duodenum, assuming that $1 \mathrm{~g}$ of bacterial nitrogen corresponded to $11.4 \mathrm{~g}$ of bacterial organic matter.

Rumen digestion and total digestion coefficients for organic matter and nitrogen, based on nutrient-indicator ratios, were corrected to represent $100 \%$ recovery of $\mathrm{Cr}_{2} \mathrm{O}_{3}$. The data were analysed in a Latin square design by variance analysis (Snedecor and Cochran, 1971).

\section{Results.}

Effect of lasalocid on rumen digestion.

a) End-products of fermentation (table 2). - The presence of lasalocid in the feed resulted in an increased amount of propionic acid in the VFA mixture which was significant ( $p<0.01$ ) when the sheep were fed 43 and $64 \mathrm{ppm}$ of lasalocid. This increase was around $14 \%$ with the $L 1$ diet $(22 \mathrm{ppm})$ and reached almost $40 \%$ with higher doses. The proportions of acetic and butyric acids lessened (table 2). The concentrations of other volatile fatty acids tended to decrease, particularly when the amount of lasalocid given exceeded $21 \mathrm{ppm}$, but the differences were significant only for valerianic acid $(p<0.05)$ and caproic acid $(p<0.01)$. The total volatile acid concentration of the rumen liquor also decreased significantly when the sheep were given 43 and 64 ppm of lasalocid. This drop was concomitant with a slight rise in $\mathrm{pH}$ noted with the experimental feeds.

The gas composition was greatly altered with diets containing 21 and $43 \mathrm{ppm}$ of lasalocid (table 2). The methane fraction dropped $20 \%$ and the $\mathrm{CO}_{2} / \mathrm{CH}_{4}$ ratio increased significantly. These differences were less with the $L 3$ diet $(64 \mathrm{ppm})$ 
TABLE 2

Effect of lasalocid sodium on rumen fermentation (means of 10 measurements and standard-deviations).

\begin{tabular}{|c|c|c|c|c|}
\hline \multirow[b]{2}{*}{ Rumen VFA } & \multicolumn{4}{|c|}{ Lasalocid sodium (ppm) } \\
\hline & $0(L 0)$ & $21(L 1)$ & 43(L2) & 64(L3) \\
\hline 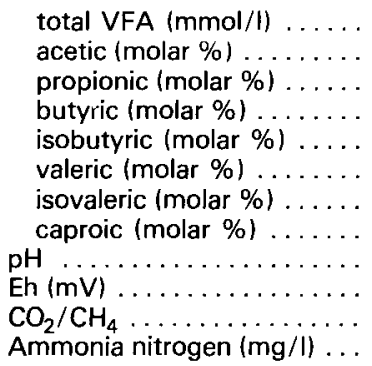 & $\begin{array}{c}74.2 \pm 4.0^{\mathrm{a}} \\
60.6 \pm 6.1^{\mathrm{a}} \\
23.2 \pm 4.4^{\mathrm{A}} \\
11.3 \pm 0.9^{\mathrm{a}} \\
0.45 \pm 0.06^{\mathrm{a}} \\
2.92 \pm 0.73^{\mathrm{a}} \\
1.45 \pm 0.81^{\mathrm{a}} \\
0.67 \pm 0.09^{\mathrm{A}} \\
5.88 \pm 0.17^{\mathrm{a}} \\
-392 \pm 55^{\mathrm{a}} \\
2.23 \pm 0.44^{\mathrm{A}} \\
154 \pm 58^{\mathrm{a}}\end{array}$ & $\begin{array}{l}73.6 \pm 15.0^{\mathrm{ab}} \\
59.0 \pm 1.7^{\mathrm{ab}} \\
26.6 \pm 3.9^{\mathrm{A}} \\
10.0 \pm 1.9^{\mathrm{ab}} \\
0.57 \pm 0.07^{\mathrm{a}} \\
2.20 \pm 0.55^{\mathrm{ab}} \\
1.25 \pm 0.76^{\mathrm{a}} \\
0.26 \pm 0.03^{\mathrm{B}} \\
5.86 \pm 0.16^{\mathrm{ab}} \\
-414 \pm 37^{\mathrm{a}} \\
2.75 \pm 0.32^{\mathrm{b}} \\
187 \pm 65^{\mathrm{a}}\end{array}$ & $\begin{array}{c}71.2 \pm 14.3^{\mathrm{bc}} \\
56.6 \pm 2.9^{\mathrm{b}} \\
32.3 \pm 5.7^{\mathrm{B}} \\
8.2 \pm 2.5^{\mathrm{b}} \\
0.32 \pm 0.04^{\mathrm{a}} \\
2.00 \pm 0.49^{\mathrm{bc}} \\
0.50 \pm 0.31^{\mathrm{a}} \\
0.22 \pm 0.04^{\mathrm{B}} \\
5.95 \pm 0.22^{\mathrm{ab}} \\
-402 \pm 27^{\mathrm{a}} \\
2.88 \pm 0.38^{\mathrm{B}} \\
152 \pm 50^{\mathrm{a}}\end{array}$ & $\begin{array}{c}70.4 \pm 10.5^{\mathrm{c}} \\
55.7 \pm 2.0^{\mathrm{b}} \\
32.5 \pm 4.5^{\mathrm{B}} \\
8.6 \pm 2.4^{\mathrm{b}} \\
0.32 \pm 0.05^{\mathrm{a}} \\
2.05 \pm 0.45^{\mathrm{c}} \\
0.45 \pm 0.43^{\mathrm{a}} \\
0.17 \pm 0.02^{\mathrm{B}} \\
6.00 \pm 0.2^{\mathrm{b}} \\
-419 \pm 32^{\mathrm{a}} \\
2.55 \pm 0.41^{\mathrm{AB}} \\
150 \pm 45^{\mathrm{a}}\end{array}$ \\
\hline
\end{tabular}

Means with different superscripts are significantly different $(A, B: P<0.01 ; a, b, c: P<0.05)$.

because the rumen gas composition in one of the 4 sheep was abnormal $\left(\mathrm{CO}_{2} / \mathrm{CH}_{4}=1.55\right)$. If the data on this animal are discarded, the average values obtained on the other 3 sheep are close to those with the other two experimental diets.

Finally, lasalocid did not alter the mean value of rumen liquor ammonia nitrogen content (table 2). The drastic increase in ammoniogenesis after feeding can be attributed to fermentation of the ureic nitrogen in the feed. After that, ammoniogenesis decreased quicker with the control than with the experimental diets (fig. 1); this would probably indicate greater bacterial synthesis when the sheep did not receive any lasalocid.

b) Microbial population. - The population of ciliate protozoa in the rumen was considerably modified with lasalocid. The protozoa included the following main strains: Entodinium sp. and Polyplastron multivesiculatum. The Polyplastron genus decreased significantly $(p<0.01)$ (table 3) with lasalocid, irrespective of the dose. In contrast, Entodinium sp. was not affected by $21 \mathrm{ppm}$ of lasalocid but decreased markedly $(p<0.01)$ when the dose was higher.

TABLE 3

Effect of lasalocid sodium on rumen microbial population (means and standard-deviations).

\begin{tabular}{|c|c|c|c|c|}
\hline \multirow[b]{2}{*}{ Rumen ciliates $\left(10^{3} / \mathrm{ml}\right)$} & \multicolumn{4}{|c|}{ Lasalocid sodium (ppm) } \\
\hline & O(LO) & $21(L 1)$ & $43(L 2)$ & $64(L 3)$ \\
\hline $\begin{array}{l}\text { - Entodinium sp. . . . . . . . . . . } \\
\text { - Polyplastron multivesiculatum }\end{array}$ & $\begin{array}{l}103.7 \pm 13.9^{A} \\
13.0 \pm 5.4^{A}\end{array}$ & $\begin{array}{r}105.1 \pm 13.2^{\mathrm{A}} \\
0.45 \pm 0.21^{\mathrm{B}}\end{array}$ & $\begin{array}{l}21.0 \pm 10.9^{B} \\
0.55 \pm 0.23^{B}\end{array}$ & $\begin{array}{c}5.2 \pm 4.7^{B} \\
0.57 \pm 0.22^{B}\end{array}$ \\
\hline $\begin{array}{l}\text { Non food-particle associated bacteria } \\
\left(10^{9} / \mathrm{ml}\right) \ldots \ldots \ldots \ldots \ldots \ldots \ldots \ldots \ldots\end{array}$ & $\begin{array}{l}6.73 \pm 0.77^{\mathrm{A}} \\
24.8 \pm 1.7^{\mathrm{A}}\end{array}$ & $\begin{array}{l}6.77 \pm 0.53^{A} \\
27.8 \pm 2.4^{B}\end{array}$ & $\begin{array}{l}6.40 \pm 1.40^{4 b} \\
26.4 \pm 1.6^{b}\end{array}$ & $\begin{array}{l}5.62 \pm 1.08^{b} \\
27.7 \pm 1.1^{B}\end{array}$ \\
\hline
\end{tabular}

Means with different superscripts are significantly different : (A, B : $P<0.01 ; a, b, c: P<0.05)$. 


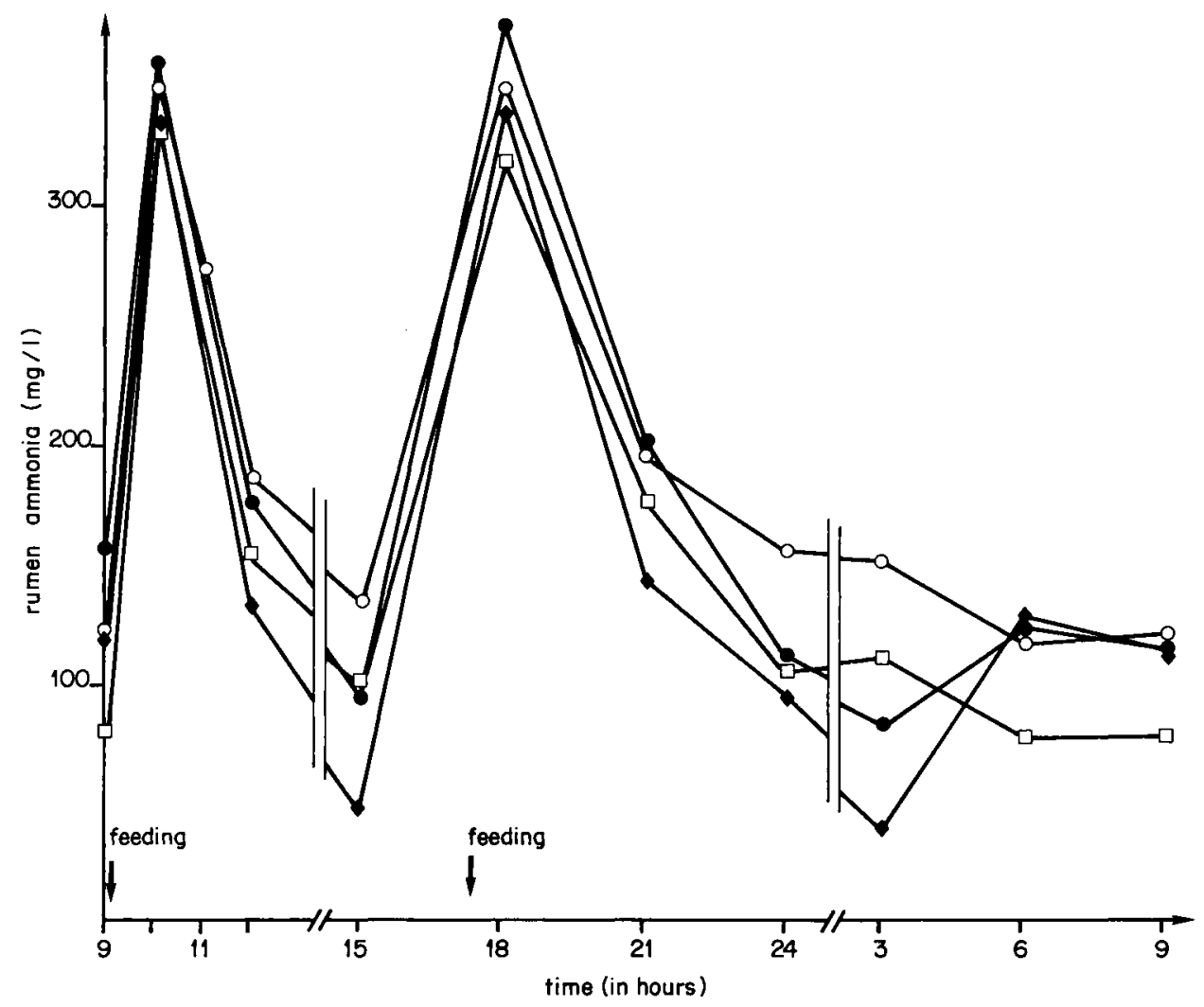

FIG. 1. - Effect of lasalocid on rumen ammonia concentration. LL1 (21 ppm of lasalocid) ; 口_L2 (43 ppm of lasalocid) ; _-L3 (64 ppm of lasalocid).

Dietary lasalocid in the $L 3$ diet $(64 \mathrm{ppm})$ caused a significant drop in the number of non-food particle-associated bacteria $(p<0.05)$. Simultaneously with these quantitative modifications in the microbial population of the rumen, we observed a significant $10 \%$ increase in the cellulolytic activity of the bacteria.

\section{Organic matter digestion (table 4).}

Lasalocid modified the extent and sites of the digestion of organic matter. Overall digestive utilization was lower with feeds that contained 43 and $64 \mathrm{ppm}$ of lasalocid. The values were only significantly different from the control values with the diet containing a higher amount of lasalocid (L3).

This depressive effect of lasalocid occurred mainly in the forestomach since it was expressed as a $12 \%$ decrease in the amount of organic matter truly digested in the rumen, whatever the lasalocid concentration in the diet (table 4). These results confirm the decrease in rumen liquor VFA concentration with lasalocid, which is significant only in the L2 and L3 diets (table 2), and cannot be attributed to increased VFA absorption since the rumen $\mathrm{pH}$ values did not decrease with lasalocid. 
TABLE 4

Effect of lasalocid sodium on the site and extent of organic matter (OM) digestion (means and standard-deviations).

\begin{tabular}{|c|c|c|c|c|}
\hline & \multicolumn{4}{|c|}{ Lasalocid sodium (ppm) } \\
\hline & O(LO) & $21(L 1)$ & 43(L2) & $64(\mathrm{~L} 3)$ \\
\hline $\begin{array}{l}\text { Intake }(g / \text { day) } \ldots \ldots \ldots \ldots \ldots \\
\text { Ruminal digestion ( } \% \text { of intake) }\end{array}$ & $823 \pm 17 a$ & $824 \pm 17^{a}$ & $827 \pm 21^{a}$ & $785 \pm 60^{\circ}$ \\
\hline $\begin{array}{l}\text { - OM apparently digested } \ldots \ldots \ldots \ldots \ldots \\
- \text { OM truly digested .................. } \\
\text { Ruminal and small intestinal digestion }(\% \text { of }\end{array}$ & $\begin{array}{l}59.5 \pm 6.2^{A} \\
79.2 \pm 6.5^{A}\end{array}$ & $\begin{array}{l}52.4 \pm 4.4^{B} \\
69.4 \pm 4.8^{B}\end{array}$ & $\begin{array}{l}55.8 \pm 4.8^{b} \\
71.2 \pm 4.3^{B}\end{array}$ & $\begin{array}{l}50.8 \pm 3.9^{\mathrm{B}} \\
68.1 \pm 4.8^{\mathrm{B}}\end{array}$ \\
\hline 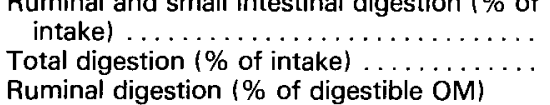 & $\begin{array}{l}81.6 \pm 3.8^{\mathrm{a}} \\
82.8 \pm 0.8^{\mathrm{a}}\end{array}$ & $\begin{array}{l}75.9 \pm 5.6^{\mathrm{a}} \\
82.8 \pm 0.1^{\mathrm{a}}\end{array}$ & $\begin{array}{l}74.2 \pm 6.8^{\mathrm{ab}} \\
80.7 \pm 3.9^{\mathrm{ab}}\end{array}$ & $\begin{array}{l}72.3 \pm 3.1^{\mathrm{B}} \\
78.5 \pm 2.5^{\mathrm{b}}\end{array}$ \\
\hline 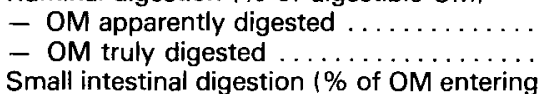 & $\begin{array}{l}71.9 \pm 7.8^{\mathrm{a}} \\
95.3 \pm 8.0^{\mathrm{A}}\end{array}$ & $\begin{array}{l}64.4 \pm 5.3^{b} \\
85.2 \pm 5.7^{8}\end{array}$ & $\begin{array}{l}69.7 \pm 4.1^{\mathrm{a}} \\
89.1 \pm 3.8^{\mathrm{b}}\end{array}$ & $\begin{array}{l}63.1 \pm 4.5^{b} \\
84.7 \pm 6.3^{8}\end{array}$ \\
\hline the duodenum)...$\ldots \ldots \ldots \ldots$ & $54.8 \pm 2.6^{a}$ & $49.0 \pm 12.8^{a}$ & $45.9 \pm 8.2^{b}$ & $43.9 \pm 1.9^{b}$ \\
\hline
\end{tabular}

Means with different superscripts are significantly different $(A, B: P<0.01 ; a, b, c: P<0.05)$.

The digestion of organic matter was quantitatively depressed in the small intestine of sheep receiving lasalocid (table 4). This was due to the lowered digestion in the forestomach that supplies the small intestine with dietary organic matter. This supply of dietary organic matter was composed of components (table 1) rich in cell-wall carbohydrates and relatively poor in starch, explaining why it was poorly hydrolysed by intestinal enzymes. Organic matter digestibility was thus very much lower at the ileum $(75.9,74.2$ and 72.3, respectively, in lasalocid-fed sheep as opposed to $81.6 \%$ in the control animals). In the large intestine, part of the organic matter was fermented by the microflora, but with diets high in lasalocid, the breakdown was insufficient to compensate for the decrease in rumen digestion.

\section{Nitrogen digestion (table 5).}

Lasalocid, given at a concentration of 21 and $43 \mathrm{ppm}$ in the feed, had no effect on nitrogen digestibility. At higher doses, its action was significantly depressive $(p<0.05)$ (70.4 instead of $76.8 \%$ ). It had no effect on nitrogen losses in the rumen which, moreover, were practically inexistent since the duodenal $\mathrm{N} / \mathrm{N}$ intake ratio was nearly 1 in the four diets studied.

On the other hand, lasalocid significantly lowered bacterial synthesis in the rumen; bacterial nitrogen as a percentage of non-ammonia duodenal nitrogen was significantly depressed when lasalocid was given $(63.1,55.6$ and $57.8 \%$, respectively, with the $L 1, L 2$ and $L 3$ diets compared to $70.5 \%$ with the control diet). Less bacterial nitrogen reached the small intestine as well. Consequently, the amount of undegraded dietary nitrogen in the rumen increased, and this increase was significant $(p<0.05)$ with diets containing 43 and $64 \mathrm{ppm}$ of lasalocid. Finally, the efficiency of microbial synthesis $(\mathrm{g}$ of bacterial nitrogen $/ 100 \mathrm{~g}$ of organic matter truly fermented in the rumen) was not signifi- 
TABLE 5

Effect of lasalocid on the site and extent of nitrogen digestion (means and standard-deviations).

\begin{tabular}{|c|c|c|c|c|}
\hline & \multicolumn{4}{|c|}{ Lasalocid sodium (ppm) } \\
\hline & $0(\mathrm{LO})$ & $21(L 1)$ & $43(L 2)$ & $64(L 3)$ \\
\hline $\begin{array}{l}\text { Intake }(\mathrm{g} / \text { day) } \\
\text { Duodenal flow of }\end{array}$ & $20.7 \pm 0.9^{a}$ & $21.1 \pm 0.6^{a}$ & $21.2 \pm 0.7^{a}$ & $20.2 \pm 1.7^{a}$ \\
\hline - total $\mathrm{N}: \mathrm{g} / \mathrm{day}$ & $20.7 \pm 0.8^{a}$ & $20.9 \pm 1.7^{a}$ & $21.4 \pm 3.2^{\mathrm{a}}$ & $21.8 \pm 2.0^{a}$ \\
\hline$\%$ of $\mathrm{N}$ intake & $100.0 \pm 4.1^{\mathrm{a}}$ & $99.0 \pm 9.2^{\mathrm{a}}$ & $100.9 \pm 10.1^{\mathrm{a}}$ & $107.9 \pm 4.0^{\mathrm{a}}$ \\
\hline - non-ammonia nitrogen (NAN) $(\mathrm{g} / \mathrm{d})$ & $20.1 \pm 0.5^{a}$ & $19.7 \pm 1.9^{\mathrm{a}}$ & $20.5 \pm 3.4^{a}$ & $20.8 \pm 1.8^{a}$ \\
\hline $\begin{aligned}- \text { bacterial } N(D A P A): & -g / \text { day } \ldots . . . \\
& -\% \text { of NAN }\end{aligned}$ & $14.2 \pm 1.5^{\mathrm{A}}$ & $12.3 \pm 0.6^{b}$ & $11.2 \pm 0.8^{B}$ & $11.9 \pm 0.5^{B}$ \\
\hline- dietary $N(1):-g /$ day $\ldots \ldots \ldots$ & $70.5 \pm 6.4^{\mathrm{a}}$ & $63.1 \pm 9.4^{b}$ & $55.6 \pm 5.5^{8}$ & $57.8 \pm 6.0^{\mathrm{B}}$ \\
\hline $\begin{aligned} & \\
& -\% \text { of } N \text { intake } . . . .\end{aligned}$ & $\begin{array}{r}5.9 \pm 1.2^{\mu} \\
28.6+6.1^{a}\end{array}$ & $\begin{array}{l}1.4 \pm 2.6^{a} \\
35.1+12.4^{a}\end{array}$ & $\begin{aligned} 9.2 \pm 2.6^{\circ} \\
43.5 \pm 11.3^{b}\end{aligned}$ & $\begin{aligned} 8.0 \pm 2.10 \\
42.5+7.7 b\end{aligned}$ \\
\hline $\begin{array}{l}\text { Bacterial nitrogen in duodenum }(\mathrm{g} / \mathrm{kg} \text { of OM } \\
\text { truly fermented in rumen)............. } \\
\text { NAN absorbed in small intestine (\% of NAN }\end{array}$ & $21.9 \pm 0.24^{\mathrm{ab}}$ & $21.5 \pm 0.11^{a b}$ & $19.1 \pm 0.20^{\mathrm{a}}$ & $22.5 \pm 0.19^{\mathrm{b}}$ \\
\hline entering duodenum) $\ldots \ldots \ldots \ldots \ldots \ldots$ & $70.1 \pm 3.4^{\mathrm{a}}$ & $67.6 \pm 2.2^{\mathrm{a}}$ & $69.0 \pm 6.4^{a}$ & $70.0 \pm 2.4^{a}$ \\
\hline$N$ digestibility $(\%)$. & $76.8 \pm 3.0^{\mathrm{a}}$ & $77.0 \pm 2.4^{\mathrm{a}}$ & $76.6 \pm 8.4^{a}$ & $70.4 \pm 1.7^{b}$ \\
\hline
\end{tabular}

(1) Included protozoal and endogenous $\mathrm{N}$.

Means with different superscripts are significantly different $(A, B: P<0.01 ; a, b,:<0.05$ ).

cantly modified by lasalocid; it was $2.19,2.15,1.91$ and 2.25 for. the LO, L1, L2 and L3 diets, respectively.

In the small intestine, nitrogen digestibility was not altered by lasalocid, despite the different composition of the nitrogen fraction of the intestinal contents. Dietary nitrogen, mainly from cereal (prolamins), was probably not much more digestible than bacterial $\mathrm{N}$, and the endogenous nitrogen portion was greater with the lasalocid diets since the amount of undegraded organic matter increased in the small intestine.

\section{Discussion.}

Lasalocid, like other ionophores or antibiotics, modifies microbial activity in the rumen considerably. Because it selects specific bacteria, it directs fermentation towards a greater production of propionic acid and less methane production. By inhibiting the development of other bacteria, it reduces the intensity of microbial synthesis and, consequently, limits feed protein breakdown. Our results demonstrate the dual action of lasalocid on energy and nitrogen utilization which will now be discussed.

The increase in the molar proportion of propionic acid in the VFA mixture as well as the drop in methane production are now well known and have been widely studied using lasalocid (Gutierrez et al., 1982 ; Herod et al., 1979 ; Horton and Stockdale, 1981 ; Ricke et al., 1981; Thonney et al., 1981), monensin (Durand, 1982 ; Fuller and Johnson, 1981 ; Jouany and Senaud, 1978 ; Nagaraja et al., 1981 ; Van Nevel and Demeyer, 1977), avoparcin (Chalupa et al., 1981) and salinomycin (McClure et al., 1980 ; Webb et al., 1980).

The results of the present study, obtained with animals fed a very different type of diet (rich in cell-wall carbohydrates) from those studied until now, confirm 
previously published data obtained with concentrate diets and can be explained by considerable modifications in the rumen ecosystem. The drastic effect of lasalocid on ciliate protozoa in the rumen, as already noted with monensin (Jouany and Senaud, 1978), has been demonstrated. It has also been shown that, beyond a certain dose, lasalocid can alter the bacterial population both quantitively and qualitatively. Our results confirm other works (Brulla and Bryant, 1980 ; Chen Min and Wolin, 1979) showing that lasalocid (or monensin) selects resistant strains such as Bacteroides that produce succinate and Selenomonas which in turn decarboxylize the succinate, transforming it into propionate. Generally speaking, lasalocid has a very antibacterial action (Durand, 1982). The effect of lasalocid on the microbial population in the rumen is expressed as a decrease in the amount of organic matter fermented and in bacterial protein synthesis in the rumen. These results are similar to others (Muntifering et al., 1981 ) noted in cattle fed cereal-rich diets (90\% corn) supplemented with 33 ppm of monensin. However, modification of the bacterial population and the reduced number of protozoa cannot alone explain these results. This is emphasized in our study since neither the number of free bacteria in the rumen liquor nor the cellulolytic activity of rumen bacteria was affected by lasalocid. The microbial population was only significantly affected by doses equal to or higher than $43 \mathrm{ppm}$. Other mechanisms may be responsible for this decrease in rumen digestion. We measured water intake during the last experimental period and noted that lasalocid induced a strong increase in the amount of water consumed. Water intake was 2.7, 3.0 and 4.0 times higher in sheep that received 21, 43 and $64 \mathrm{ppm}$ of lasalocid, respectively, than in the controls. These observations should be studied on a larger number of animals, but the increased water intake is likely to lead to accelerated turnover of the liquid fraction in the rumen, especially if the amount of salt (accessible at all times) ingested also increases (Harrison et al., 1975). Lasalocid would thus play a part in limiting the development of the microbial population. On the other hand, it could contribute to accelerating the rate of digesta transit towards the small intestine, thus reducing feed digestion in the rumen.

The lower digestion of organic matter in the rumen could be compensated for by greater digestion in the small intestine and/or the large intestine. As previously stated, with the type of diet we used, the cell-wall carbohydrate fraction of the dietary organic matter that is not degraded in the rumen cannot be hydrolysed in the small intestine. It can be hydrolysed in the large intestine, and the depressive effect of lasalocid partially or totally disappears according to the dose. The extent to which compensation occurs would then be definitely a function of the amount of organic matter reaching the large intestine and of the lasalocid concentration of digesta which, if too high, could again reduce microbial activity in the large intestine. With a high cereal diet containing lasalocid, more starch would escape rumen fermentation and be digested in the small intestine, as shown by Muntifering et al. (1981) using monensin. This would be advantageous for improving the utilization of cereal-rich diets in the ruminant since glucose from the intestinal hydrolysis of starch is better utilized than the VFA supplied by rumen fermentation. Thus, it is difficult to foresee the effect of lasalocid on the 
overall digestion of organic matter since it will be both a function of the diet type and of the dose. However, the digestion of organic matter does not seem to decrease as long as the dose given does not exceed 50 ppm (Berger et al., 1981 ; Geay, unpublished data; Horton and Stockdale, 1981). Beyond this dose, a significantly depressive effect has been shown, but further work is required using other diets containing different amounts of starch and cell-wall carbohydrates.

Lasalocid modifies microbial activity in the rumen and thus lowers the proportion of dietary nitrogen degraded there, allowing the animal to make better use of dietary proteins. But the antimicrobial effect of lasalocid can be a disadvantage if the diet given is rich in non-protein nitrogen because the utilization of this nitrogen in microbial synthesis then decreases. Lastly, lasalocid was found to have a depressive effect on nitrogen digestion only with the L3 diet $(64 \mathrm{ppm})$; this decrease was probably due to greater faecal nitrogen excretion caused by an increase in the fermentation of organic matter in the large intestine.

\section{Conclusion.}

Lasalocid generally has a favourable effect in the ruminant, modifying energy and nitrogen digestion to make better use of the feed. The increased production of propionic acid and the decreased formation of methane in the rumen, as well as the increase in the amount of starch digested as glucose in the small intestine, all bring about improved utilization of dietary energy. These digestive manipulations are due to a modification in microbial rumen activity under the influence of lasalocid. This activity is generally low, leading to a decrease in bacterial synthesis and thus in the amount of bacterial nitrogen that reaches the duodenum. The proportion of undegraded dietary nitrogen in the rumen increases; this could be of particular interest when using protein feed sources that are well-balanced in essential amino acids. In contrast, too great a reduction in microbial activity would be detrimental to the utilization of non-protein nitrogen. It could limit the use of lasalocid in diets with a high soluble nitrogen content (more than 40 to $50 \%$ of the total nitrogen). All these digestive modifications, including the inhibitory effect of lasalocid on lactic formation (Nagaraja et al., 1982) (which reduces the risk of acidosis) and on the development of coccidiae in the digestive tract (Foreyt et al., 1981), lead to the conclusion that this ionophore antibiotic can be used profitably in ruminant feeding, provided that it is totally harmless to the animal and to the consumer.

On the whole, these results indicate that, with the feed used, the optimal dose of lasalocid should not exceed 45 to $50 \mathrm{ppm}$. Beyond this dose, lasalocid can have a negative effect, decreasing the digestibility of organic matter and nitrogen. These results generally corroborate other work, but the effects of lasalocid have been found to depend on the diet given (Geay, unpublished data), and the optimal dose is also a function of this parameter. 
Acknowledgements. - The authors wish to thank Hoffman-Laroche Cie, 52, Boulevard du Parc, 92521 Neuilly-sur-Seine, France for its financial support. They are also grateful to Dr. J. Senaud and the staff of the "Laboratoire de la Digestion " for their valuable contribution in setting up the experiment.

Résumé. Action du lasalocide de sodium sur les fermentations du rumen et la digestion chez le mouton.

Quatre moutons adultes ont reçu successivement 4 régimes suivant un schéma en carré latin. Les animaux portaient des canules du rumen et des canules simples au niveau du duodénum et de l'iléon.

Au régime de base $\left(L_{0}\right)$, constitué de pulpes de betteraves surpressées et ensilées $(56,2 \%)$, de céréales (orge et maïs, $27,6 \%)$, d'urée $(1,5 \%)$, de paille de blé haché $(14,1 \%)$, on a ajouté du lasalocide de sodium pour obtenir des doses finales de $21 \mathrm{ppm}$ (régime $L_{1}$ ), $43 \mathrm{ppm}$ (régime $L_{2}$ ) et $64 \mathrm{ppm}$ (régime $L_{3}$ ) (tabl. 1).

Dans le rumen, la présence de lasalocide a significativement augmenté la proportion molaire de l'acide propionique dans le mélange des acides gras volatils, aux dépens de celles des acides acétique et butyrique ; la concentration totale des AGV a diminué surtout avec les doses 43 et $64 \mathrm{ppm}$ (tabl. 2). Corrélativement la proportion de méthane dans les gaz du rumen a diminué. La population des ciliés a été systématiquement plus faible chez les animaux recevant les régimes expérimentaux $L_{1}$, $L_{2}$ et surtout $L_{3}$. La population des bactéries libres a également diminué ; le seuil de signification a été atteint avec la dose la plus forte $\left(L_{3}\right)$. Dans le même temps, l'activité cellulolytique des bactéries a été accrue de $10 \%$, ce qui traduit des modifications qualitatives de la population bactérienne du rumen (tabl. 3 ).

L'utilisation digestive globale de la matière organique $(\mathrm{MO})$ des rations qui a été diminuée en présence de lasalocide, s'explique surtout par une réduction importante de la digestion dans les préestomacs (12\%) (tabl. 4). L'apport plus important de MO particulièrement riche en glucides pariétaux avec ces régimes dans le duodénum justifie la diminution de la digestibilité dans l'intestin grêle des animaux recevant les régimes $L_{1}$ et surtout $L_{2}$ et $L_{3}$. II n'y a pas de compensation significative de la digestion au niveau du gros intestin.

La composition de l'azote non ammoniacal entrant dans le duodénum des moutons nourris avec les régimes expérimentaux est différente de celle observée avec le régime témoin ( $\left.L_{0}\right)$ (tabl. 3 ) : la quantité de protéines microbiennes est significativement plus faible, alors que la part de protéines alimentaires non dégradées dans le rumen est plus importante. L'efficacité de la synthèse microbienne (g protéines bactériennes $/ \mathrm{kg}$ MO réellement digérée dans le rumen) n'est pas significativement modifiée par la présence de lasalocide.

L'ensemble des changements observés sur la digestion de ces régimes, dus à la présence de lasalocide, s'expliquent par des modifications dans la composition qualitative et quantitative de la population microbienne du rumen. Les répercussions sur l'utilisation de l'azote et de l'énergie des rations sont importantes.

\section{References}

BARTLEY E. E., HEROD E. L., BECHTLE R. M., SAPIENZA D. A., BRENT B. E., 1979. Effect of monensin or lasalocid, with and without niacin or amicloral, on rumen fermentation and feed efficiency. J. anim. Sci., 49, 1066-1075.

BERGER L. L., RICKE S. C., FAHEY G. C., 1981. Comparison of two forms and two levels of lasalocid with monensin on feedlot cattle performance. J. anim. Sci., 53, 1440-1445.

BRULLA W. J., BRYANT M. P., 1980. Monensin induced changes in the major species of the rumen bacterial population. Abst. Annu. Meet. am. Soc. Microbiol., 104.

CHALUPA W., OPPEgARD C., WILliAMS H. C., BLOCK B., PERKINS G., 1981. Effect of avoparcin on rumen environment and fermentation. J. anim. Sci., 53 (Suppl. 1), 387 (Abstr.).

CHEN MIN, WOLIN M. J., 1979. Effect of monensin and lasalocid sodium on the growth of methanogenic and rumen saccharolytic bacteria. Appl. environ. Microbiol., 38, 72-77.

DURAND M., 1982. Orientation du métabolisme du rumen au moyen des additifs. Ann. Zootechn., 31, 47-76. 
FOREYT J., PARISH S. M., FOREYT K. M., 1981. Lasalocid for improved weight gains and control of coccidia in lambs. Am. J. vet. Res., 42, 57-60.

FULLER J. R., JOHNSON D. E., 1981. Monensin and lasalocid effects on fermentation in vitro. J. anim. Sci, 53, 1574-1580.

GUTIERREZ G. G., SCHAKE L. M., BYERS F. M., 1982. Whole-plan grain sorghum silage processing and lasalocid effects on stocker calf performance and rumen fermentation. $J$. anim. Sci., 54, 863-868.

HARRISON D. G., BEEVER D. E., THOMSON D. J., OSBOURN D. F., 1975. Manipulation of rumen fermentation in sheep by increasing the rate of flow of water from the rumen. $J$, agric. Sci., Camb., 85, 93-101.

HEROD E. L., BARTLEY E. E., DAVIDOVITCH A., BECHTLE R. M., SAPIENZA D. A., BRENT B. E., 1979. Effect of adaptation to monensin or lasalocid on rumen fermentation in vitro and the effect of these drugs on heifer growth and feed efficiency. J. anim. Sci., 49 (suppl. 1), 374 (Abstr.).

HORTON G. M. J., STOCKDALE P. H. G., 1981. Lasalocid and monensin in finishing diets for early weaned lambs with naturally occurring coccidiosis. Am. J. vet. Res., 42, 433-436.

JOUANY J. P., 1982. Volatile fatty acid and alcohol determination in digestive contents, silage juices, bacterial cultures and anaerobic fermentor contents. Sciences des Aliments, 2, $131-144$.

JOUANY J. P., SENAUD J., 1978. Utilisation du monensin dans la ration des ruminants. II. Effects sur les fermentations et la population microbienne du rumen. Ann. Zootech., 27, 61-74.

JOUANY J. P., SENAUD J., 1979. Description d'une technique permettant d'effectuer des prélèvements répétés de gaz dans le rumen. Ann. Biol. anim. Bioch. Biophys., 19, 1007-1010.

JOUANY J. P., SENAUD J., 1982. Influence des ciliés du rumen sur la digestion de différents glucides chez le mouton. I. Utilisation des glucides pariétaux (cellulose et hémicellulose) et de l'amidon. Reprod. Nutr. Dévelop., 22, 735-752.

MATHIESON J., 1970. The automated estimation of chromic oxide. Proc. Nutr. Soc., 20, 30A.

McARTHUR J. M., MILTIMORE J. E., 1961. Rumen gas analysis by gas-solid chromatography. Can. J. anim. Sci., 41, 187-195.

McCLURE W. H., FONTENOT J. P., WEBB K. E., LUCAS D. M., 1980. Feedlot performance of cattle fed different salinomycine levels. J. anim. Sci., 51 (suppl. 1), 380 (Abstr.).

MICHEL M. M., 1971. Analyse quantitative de quelques substances azotées et glucidiques en milieu biologique, essai de rationalisation. Th. Univ. Clermont-Ferrand, $n^{\circ}$ d'ordre $43,79 \mathrm{pp}$.

MUNTIFERING R. B., THEURER B., NOON T. H., 1981. Effects of monensin on site and extent of whole-corn digestion and bacterial protein synthesis in beef steers. J. anim. Sci., 53, 1565-1573.

NAGARAJA T. G., AVERTY T. B., BARTLEY E. E., GALITZER S. J., DAYTON A. D., 1981. Prevention of lactic acidosis in cattle by lasalocid or monensin. J. anim. Sci., 53, 206-216.

NAGARAJA T. G., AVERTY T. B., BARTLEY E. E., ROOF S. K., DAYTON A. D., 1982. Effect of lasalocid, monensin or thiopeptin on lactic acidosis in cattle. J. anim. Sci., 54, 649-658.

RICKE S. C., BERGER L. L., FAHEY G. C., 1981. Effect of lasalocid and monensin on dry matter digestibility and nitrogen retention in lambs. J. anim. Sci., 53 (suppl. 1), 426 (Abstr.).

SNEDECOR G. W., COCHRAN W. G., 1971. Classification à 2 entrées, modèle du carré latin. In Méthodes statistiques, $6^{e}$ éd., Assoc. Coord. Techn. agric., Paris.

THONNEY M. L., HEIDE E. K., DUHAIME D. J., HAND R. J., PEROSIO D. J., 1981. Growth, feed efficiency and metabolite concentrations of cattle fed high forage diets with lasalocid or monensin supplements. $J$. anim. Sci., 52, 427-433.

TISSERAND J. L., COLEOU J., ZELTER Z., 1962. Emploi du sesqui-oxyde de chrome comme indicateur dans les études de bilan digestif chez le ruminant. C. R. Acad. Sci., Paris, 254, 2233-2235.

VAN NEVEL C. J., DEMEYER D. I., 1977. Effect of monensin on rumen metabolism in vitro. Appl. environ. Microbiol., 34, 251-257.

- WEBB K. E., FONTENOT J. P., LUCAS D. M., 1980. Metabolism studies in steers fed different levels of salinomycin. J. anim. Sci., 51 (suppl. 1), 407 (Abstr.). 